\title{
Is TrpM5 a reliable marker for chemosensory cells? Multiple types of microvillous cells in the main olfactory epithelium of mice Anne Hansen* and Thomas E Finger
}

\author{
Address: Rocky Mountain Taste and Smell Center, Dept. of Cell and Developmental Biology, School of Medicine, University of Colorado Denver, \\ Aurora, CO 80045, USA \\ Email: Anne Hansen* - Anne.Hansen@uchsc.edu; Thomas E Finger - Tom.Finger@uchsc.edu \\ * Corresponding author
}

Published: 4 December 2008

BMC Neuroscience 2008, 9:1 I5 doi:10.1/86/147|-2202-9-II5

This article is available from: http://www.biomedcentral.com//47/-2202/9/II5

(C) 2008 Hansen and Finger; licensee BioMed Central Ltd.

This is an Open Access article distributed under the terms of the Creative Commons Attribution License (http://creativecommons.org/licenses/by/2.0), which permits unrestricted use, distribution, and reproduction in any medium, provided the original work is properly cited.
Received: 30 July 2008

Accepted: 4 December 2008

\begin{abstract}
Background: In the past, ciliated receptor neurons, basal cells, and supporting cells were considered the principal components of the main olfactory epithelium. Several studies reported the presence of microvillous cells but their function is unknown. A recent report showed cells in the main olfactory epithelium that express the transient receptor potential channel TrpM5 claiming that these cells are chemosensory and that TrpM5 is an intrinsic signaling component of mammalian chemosensory organs. We asked whether the TrpM5-positive cells in the olfactory epithelium are microvillous and whether they belong to a chemosensory system, i.e. are olfactory neurons or trigeminally-innervated solitary chemosensory cells.

Results: We investigated the main olfactory epithelium of mice at the light and electron microscopic level and describe several subpopulations of microvillous cells. The ultrastructure of the microvillous cells reveals at least three morphologically different types two of which express the TrpM5 channel. None of these cells have an axon that projects to the olfactory bulb. Tests with a large panel of cell markers indicate that the TrpM5-positive cells are not sensory since they express neither neuronal markers nor are contacted by trigeminal nerve fibers.

Conclusion: We conclude that TrpM5 is not a reliable marker for chemosensory cells. The TrpM5-positive cells of the olfactory epithelium are microvillous and may be chemoresponsive albeit not part of the sensory apparatus. Activity of these microvillous cells may however influence functionality of local elements of the olfactory system.
\end{abstract}

\section{Background}

Traditionally, the main olfactory epithelium (MOE) of mammals was said to contain only basal cells, supporting cells, and ciliated olfactory receptor neurons (ORNs) that utilize OR-type receptor molecules and the canonical Gprotein-coupled transduction pathway via Goolf, adenylyl cyclase III (ACIII), and cAMP [1]. However, a review of the literature suggests that this conventional view is too simplistic, e.g. microvillous ORNs are present in the olfac- tory epithelium of fishes and in the vomeronasal organ of mammals. Also, microvillous cells have been reported for the MOE of some mammals including humans [2-5]. A study by Rowley et al. utilizing HRP tracing claimed that at least some microvillous cells project directly to the olfactory bulb [6]. Braun and Zimmermann [4], utilizing ecto-5'-nucleotidase as a marker, detected microvillous cells in the MOE and suggested a mechanosensory function for these elements. Carr et al. reported microvillous 
cells in rats and concluded that these cells were non-sensory cells [7]. Functional studies revealed that mice with a disrupted CAMP pathway of ciliated ORNs are still able to detect certain odorants and conspecific chemosignals $[8,9]$ suggesting the presence of non-traditional transduction mechanisms. Interestingly, further studies on the transduction pathway(s) present in the olfactory epithelium of rodents led to the conclusion that some types of transient receptor channels, e.g. TrpC6 or TrpM5, are expressed in what appear to be microvillous cells in the olfactory epithelium $[10,11]$. Kaske et al. examined various tissues containing cells that express the TrpM5 channel and postulated that TrpM5 is a potential marker for chemosensory cells [12]. Lin et al. (companion paper, this issue) describe cells in the main olfactory epithelium that express the transient receptor channel TrpM5. These cells are microvillous, but vary in size and morphology.

The goal of this study was to further examine the microvillous cells in the olfactory epithelium at the light and electron microscopic level in order to ascertain whether they meet the criteria of sensory or non-sensory cells. If these cells are sensory cells they should either project an axon to the olfactory bulb as do ORNs, or they should form contacts with sensory nerve fibers like the solitary chemosensory cells or other types of sensory cells (e.g. hair cells, Merkel cells). We describe several types of microvillous cells, discuss their features, and conclude that the main olfactory epithelium of mice contains multiple subtypes of microvillous cells and that TrpM5 is not necessarily a marker for sensory cells.

\section{Methods \\ Animals}

Wild-type (C57BL/6) and TrpM5-GFP mice were bred in the animal facilities of the University of Colorado Denver, Medical School. TrpM5-GFP mice (kindly provided by Dr. Robert Margolskee, Mount Sinai School of Medicine, New York) contain a TrpM5-GFP construct including $11 \mathrm{~kb}$ of mouse TrpM5 5' flanking sequence, TrpM5 exon 1 (untranslated), intron 1, and the untranslated part of exon 2 , and eGFP [13]. We used the polymerase chain reaction (PCR) to genotype the offspring for the presence of GFP. Animals were 1 to 6 months old. All procedures were in compliance with the University of Colorado Animal Care and Use Committee.

\section{Light microscopy}

Mice were anesthetized with $20 \%$ chloral hydrate $(2 \mathrm{mg} / \mathrm{g}$ body weight), perfused transcardially with $0.9 \%$ saline followed by $4 \%$ paraformaldehyde in $0.1 \mathrm{M}$ phosphate buffer (PB). The olfactory organs were dissected and postfixed in the same fixative for $15 \mathrm{~min}$ to overnight. Cryoprotection was carried out in 30\% sucrose overnight. Cryosections $(12-14 \mu \mathrm{m})$ were mounted on Superfrost
Plus slides (VWR, West Chester, PA) and frozen at $-80^{\circ} \mathrm{C}$ until further use. Standard immunocytochemical procedures were used. Briefly, cryosections were rinsed in $0.1 \mathrm{M}$ phosphate buffered saline (PBS), blocked in blocking solution containing $1 \%$ BSA, 3\% normal donkey serum, and $0.3 \%$ Triton X-100 in PBS for 2 hours, and then incubated in the primary antisera overnight to 2 days. For details of antibodies see Table 1. After 3 washes, $20 \mathrm{~min}$ each, the sections were incubated in the appropriate secondary antibodies (Alexa 488, Alexa 568, 1:400; Invitrogen, Carlsbad, CA) for 2 hours at room temperature. After incubation, sections were washed 3 times $20 \mathrm{~min}$ and coverslipped with Fluormount-G (Fisher Biotech, Birmingham, AL). Control slides were treated either without the primary antibody or it was substituted by normal rabbit serum. Where available, the antisera were adsorbed with the appropriate peptides. Control sections showed no labeling. Sections were viewed under a fluorescence microscope or a confocal laser microscope (Olympus; Center Valley, PA).

\section{Dil tracing}

Wild-type and TrpM5-GFP mice were perfused as described above. The heads were collected and fixed in $4 \%$ PFA overnight. Then the skull above the olfactory bulbs was opened. A small crystal of DiI (Molecular Probes; Eugene, OR) was placed into each olfactory bulb close to the cribriform plate by means of an insect pin. The skull was closed with a layer of $2 \%$ agar. Then the heads were placed in 4\% PFA at room temperature for 3 to 4 weeks. After incubation the olfactory organs were dissected and embedded in 15\% gelatin (Sigma; St. Louis, MO). 40 to 50 micron sections were cut on a vibratome (Ted Pella, Inc.; Redding, CA) and viewed under a fluorescence microscope or a confocal laser microscope (Olympus; Center Valley, PA). The DiI had traveled into all areas of the olfactory epithelium.

\section{Transmission electron microscopy}

Wild-type mice: Mice were anesthetized and perfused with saline as before but the fixative was $4 \%$ glutaraldehyde in $0.1 \mathrm{M}$ phosphate buffer. The olfactory organs were dissected and postfixed in the same fixative overnight. After rinsing in phosphate buffer, the tissue samples were postfixed with $1 \%$ osmium tetroxide for $2 \mathrm{~h}$. The fixed specimens were dehydrated in a graded series of ethanol and acetone and embedded in Epon-Araldite (Electron Microscopy Sciences, Hatfield, PA). Ultrathin sections (silver to gold) were stained with uranyl acetate and lead citrate and examined with a FEI Tecnai $G^{2}$ electron microscope (Philips, Eindhoven, Netherlands).

Transgenic mice: For immunolabeling at the electron microscopic level, the animals were perfused, cryoprotected and processed as described for Light Microscopy 
Table I: Antisera used to characterize TrpM5 cells

\begin{tabular}{|c|c|c|c|}
\hline Antisera against & Marker for & Company & Lot \\
\hline Calbindin & calcium-binding protein involved in calcium signaling & SWANT CB38 & 9.03 \\
\hline Calretinin & calcium-binding protein involved in calcium signaling & SWANT 7699/4 & 18299 \\
\hline CGRP & trigeminal nerve fibers & Peninsula Lab. T-4032 & 040826-4 \\
\hline Chromogranin A & neuroendocrine cells & Santa Cruz Sc- 1488 & D0507 \\
\hline CKI8 & supporting cells & Chemicon MAB3234 & 0507004430 \\
\hline Espin & actin-binding protein in microvilli & Dr. J. Bartles, Northwestern University, Chicago & - \\
\hline GFP & green fluorescent protein & Abcam AB290 & 207431 \\
\hline Galphaq/I I & G-protein subunit q/II//4 - transduction component & Santa Cruz Sc-392 & FII07 \\
\hline IP3R3 & IP3 receptor 3 - transduction component & Chemicon AB9076 & 25041643 \\
\hline $\mathrm{Na}^{+}, \mathrm{K}^{+}-\mathrm{ATPase}$ & sodium-potassium pump & Biogenesis 0126-2000 & $773 / 272892$ \\
\hline NSE & neuronal and neuroendocrine cells & DAKO M0878 & 05437 \\
\hline PDE2A & transduction component & Santa Cruz Sc-17227 & L0402 \\
\hline PGP 9.5 & neuronal and neuroendocrine cells & AbD Serotec 7663-0504 & $07 \mid 207$ \\
\hline OMP & olfactory neurons & Dr. F. Margolis, University of Maryland & - \\
\hline $\mathrm{P} 2 \mathrm{X} 2$ & purinergic receptor - transduction component & Alomone Labs APR003 & AN-06 \\
\hline $\mathrm{P} 2 \times 3$ & purinergic receptor - transduction component & Chemicon AB5895 & 0602021455 \\
\hline PDE2A & transduction component & Santa Cruz Sc-I7227 & L0402 \\
\hline PGP 9.5 & neuronal and neuroendocrine cells & AbD Serotec 7663-0504 & 071207 \\
\hline PLCbeta2 & transduction component & Santa Cruz Sc-206 & B0907 \\
\hline SNAP 23 & synapses & SynapticSystems III 202 & - \\
\hline SNAP 25 & synapses & Calbiochem NEIOI4 & 30933 \\
\hline Substance $P$ & trigeminal nerve fibers & Accurate YMCI02I & E9381 \\
\hline SUS-I & supporting cells in the main olfactory epithelium & gift of Dr. F. Margolis, University of Maryland & - \\
\hline SV2 & synapses and some nerve fibers & Developmental Hybridoma Bank & - \\
\hline Synaptophysin & synapses & Epitomics I485-I & YE269 \\
\hline Substance $P$ & trigeminal nerve fibers & Accurate YMCI02I & E9381 \\
\hline TrpC6 & $\begin{array}{l}\text { transient receptor potential channel } \mathrm{C} 6 \text { - transduction } \\
\text { component }\end{array}$ & Abcam ABI 2249 & 342108 \\
\hline VAChT & "membrane transport protein" & Chemicon $\mathrm{ABI} 578$ & 24080681 \\
\hline Villin & actin-binding protein in microvilli & Beckman-Coulter 0258 & ID2C3 \\
\hline
\end{tabular}

with the following exceptions: 30 to 50 micron floating sections were cut and collected in 0.1 M PBS and treated with $3 \% \mathrm{H}_{2} \mathrm{O}_{2}$ for $15 \mathrm{~min}$. Triton X-100 was replaced with $1 \%$ saponin. Incubation times were extended to 3 days for primary antibodies and overnight for secondary antibodies. Secondary antibodies were biotinylated and visualized with standard $A B C / D A B$ methods. After the $D A B$ reaction the sections were washed in $\mathrm{PB}$ and postfixed in $4 \%$ glutaraldehyde overnight followed by a rinse in PB and postfixation in $1 \%$ osmium tetroxide for $1 \mathrm{~h}$. Then the sections were treated as described for Electron Microscopy of wild-type mice and embedded between two Aclar sheets (Ted Pella; Redding, CA). Some of the ultrathin sections were viewed without uranyl acetate and lead citrate staining.

Figures were created in Adobe Photoshop, Version 7.1. In some micrographs dirt spots were removed with the clone stamp tool from areas where no tissue was involved.

\section{Results}

In transgenic mice where the TrpM5 promoter drives the expression of green fluorescent protein (GFP), GFP-positive cells are scattered throughout the main olfactory epi- thelium (Fig. 1). Lin et al. [14] focused on the TrpM5positive ORN population whereas the current paper and a companion paper (Lin et al., this issue) examine nonORN cell types.

Even at the light microscopic level, several morphological types of GFP-positive cells are obvious. The typical morphology of ORNs is evident in specimens backfilled with DiI from the cribriform plate. The ORNs are long slender bipolar cells with a thin dendrite bearing an olfactory knob with laterally radiating cilia (Fig. 1C, D). At the base of the ORN, an axon tapers towards the basal lamina (Fig. $1 \mathrm{C}, \mathrm{D})$ and aggregates with other ORN axons to form olfactory nerve fascicles. These fascicles penetrate the basal lamina and form the fila olfactoria. The majority of these TrpM5-GFP-positive ORNs lie in the ventrolateral zone of the MOE. Only a few, faint TrpM5-GFP-positive ORNs were present in other areas.

Non-ORN type GFP-positive cells are scattered throughout the main olfactory epithelium without an obvious pattern (Fig. 1A, B). These cells reach the surface of the epithelium but are shorter than ciliated ORNs; some span about half of the height of the $\mathrm{OE}$, others span only the 


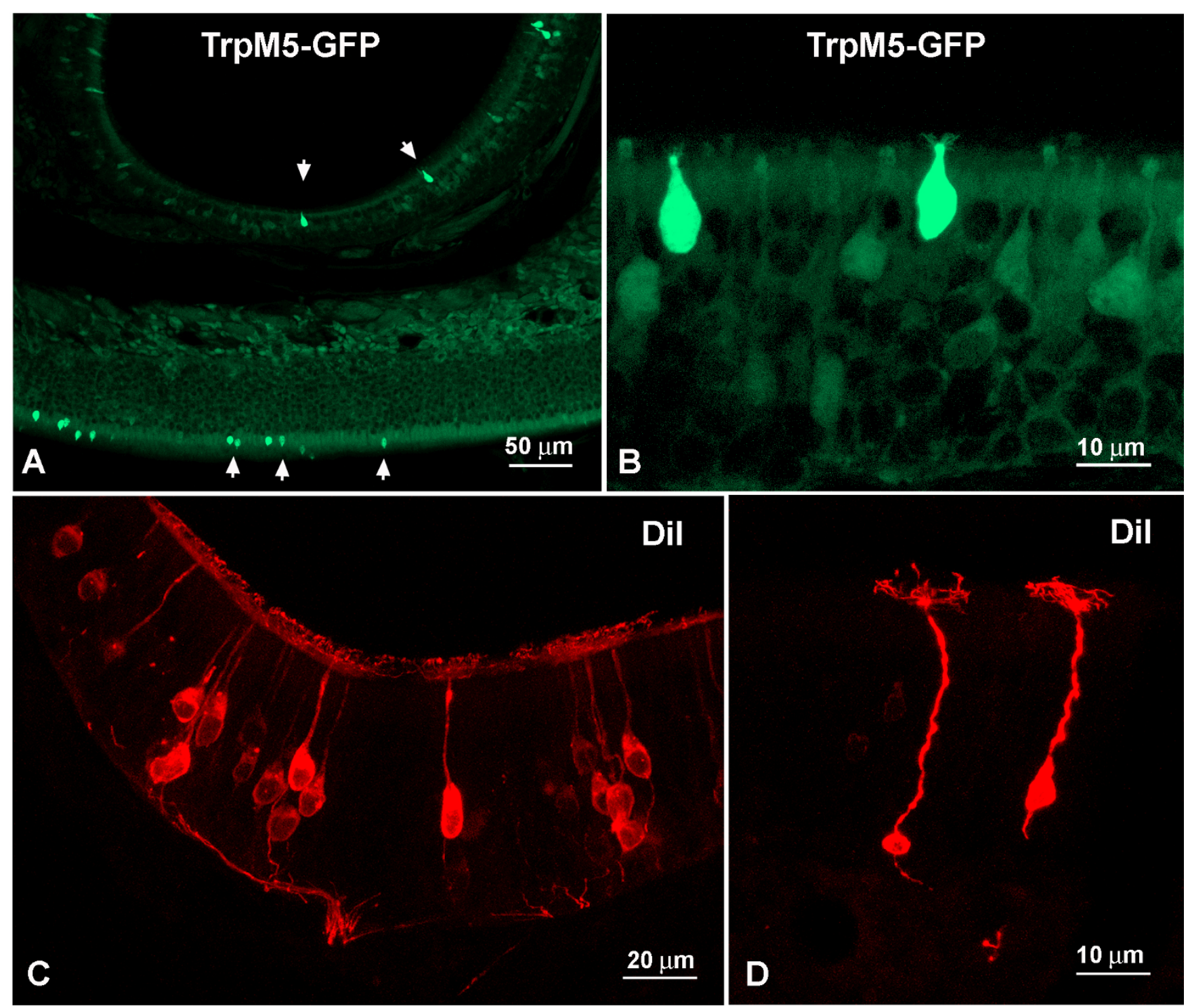

Figure I

Cell types in the MOE of mice. A Different types of microvillous cells (MV) (arrows) in the MOE labeled by GFP. Note that the olfactory epithelium varies in thickness. B Higher magnification of TrpM5a MV cells. C ORNs retrogradely labeled from the olfactory bulb by Dil. D Typical long slender ciliated ORNs retrogradely labeled by Dil.

uppermost third (Fig. 1A, B). The upper portion of these cells is usually thicker than the dendrites of the typical ciliated ORNs. The apical appendages of these TrpM5-GFPpositive cells are shorter than the cilia of regular ORNs. The TrpM5-GFP label of these shorter cells is much brighter than that of the ORNs.

Since the light microscopic level does not allow for detailed description of cell features we processed wildtype and TrpM5-GFP mouse OE for electron microscopy. These experiments revealed multiple microvillous cell types. As a preliminary classification we call these micro- villous cells TrpM5a type, TrpM5b type, and a non-TrpM5 type on the basis of GFP-experiments and ultrastructural features. All 3 cell types occur in the main olfactory epithelium between ciliated ORNs and supporting cells (Fig 2A). The nuclei of the 3 microvillous cell types show a checkerboard pattern that typically has been used to distinguish ORN nuclei from the more homogenous nuclei of the supporting cells (Fig. 2B, D, G; 3C). In none of the 3 cell types described here did serial ultrathin sections reveal an axon penetrating the basal lamina. As our immunohistochemical experiments reveal (see below), the population of non-TrpM5 type microvillous cells consists most likely 

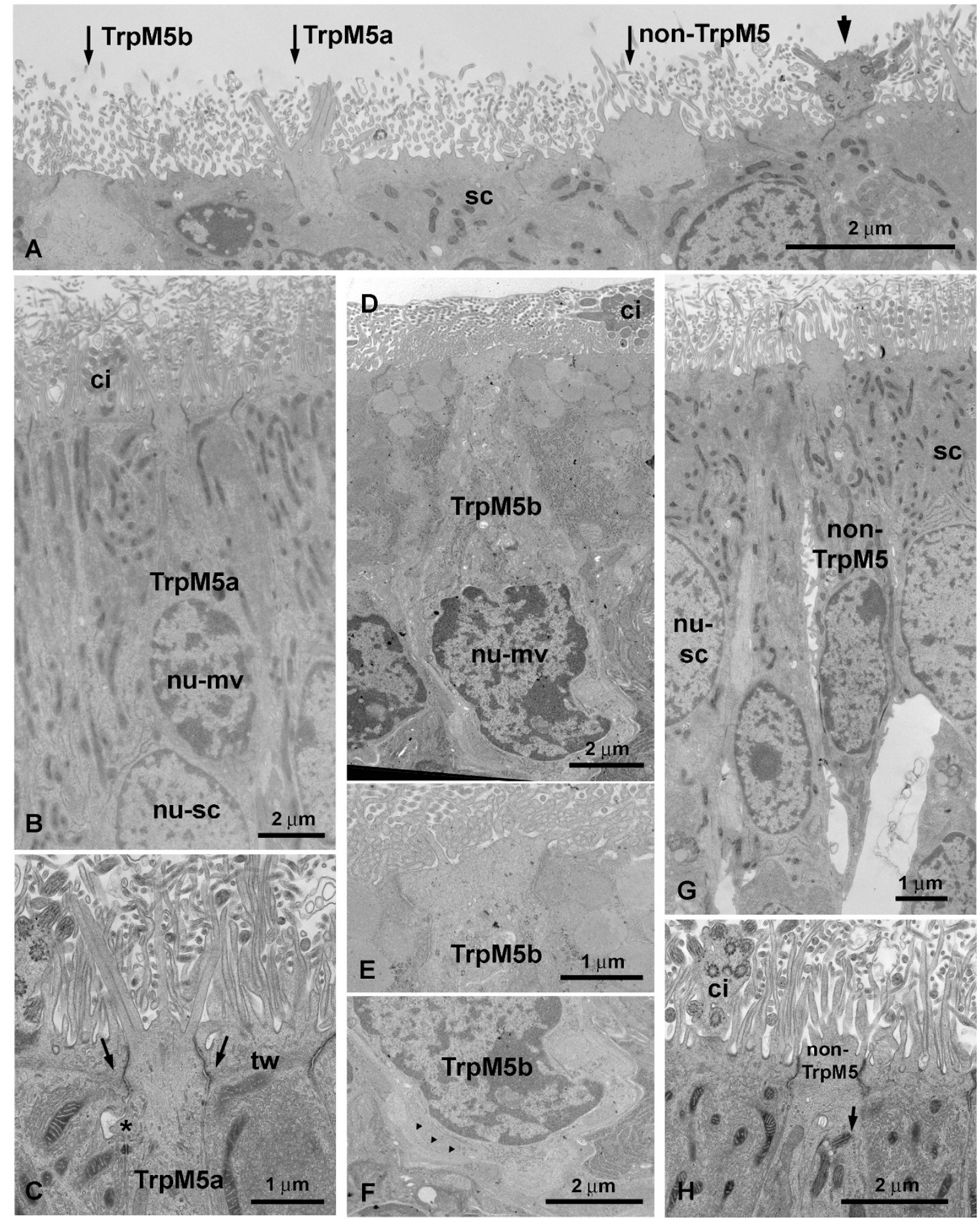

\section{Figure 2}

Electron micrographs of different MV cells in the MOE of wild type mice. A Apices of cells in the MOE. Thick arrow: ciliated ORN, thin arrows: different types of MV cells. B TrpM5a MV cell with "stiff" microvilli. nu-mv - nucleus of MV cell; nusc - nucleus of supporting cell (SC). C Higher magnification of apex of TrpM5a MV cell in B. tw: The terminal web does not continue in the TrpM5a MV cell (arrows). (*)"spine"; ci - ciliated ORN. D TrpM5b MV cell. ci - ciliated ORN; nu-mv - nucleus of MV cell. E Higher magnification of cell apex in D. F Higher magnification of basal part of TrpM5b MV cell. Small protrusions interdigitate with other cells (arrowheads). G A non-TrpM5 MV cell with a tapering basal part. nu-sc - nucleus of SC. H Higher magnification of a non-TrpM5 MV cell. Arrow - centriole with rootlet; ci - ciliated ORN. 

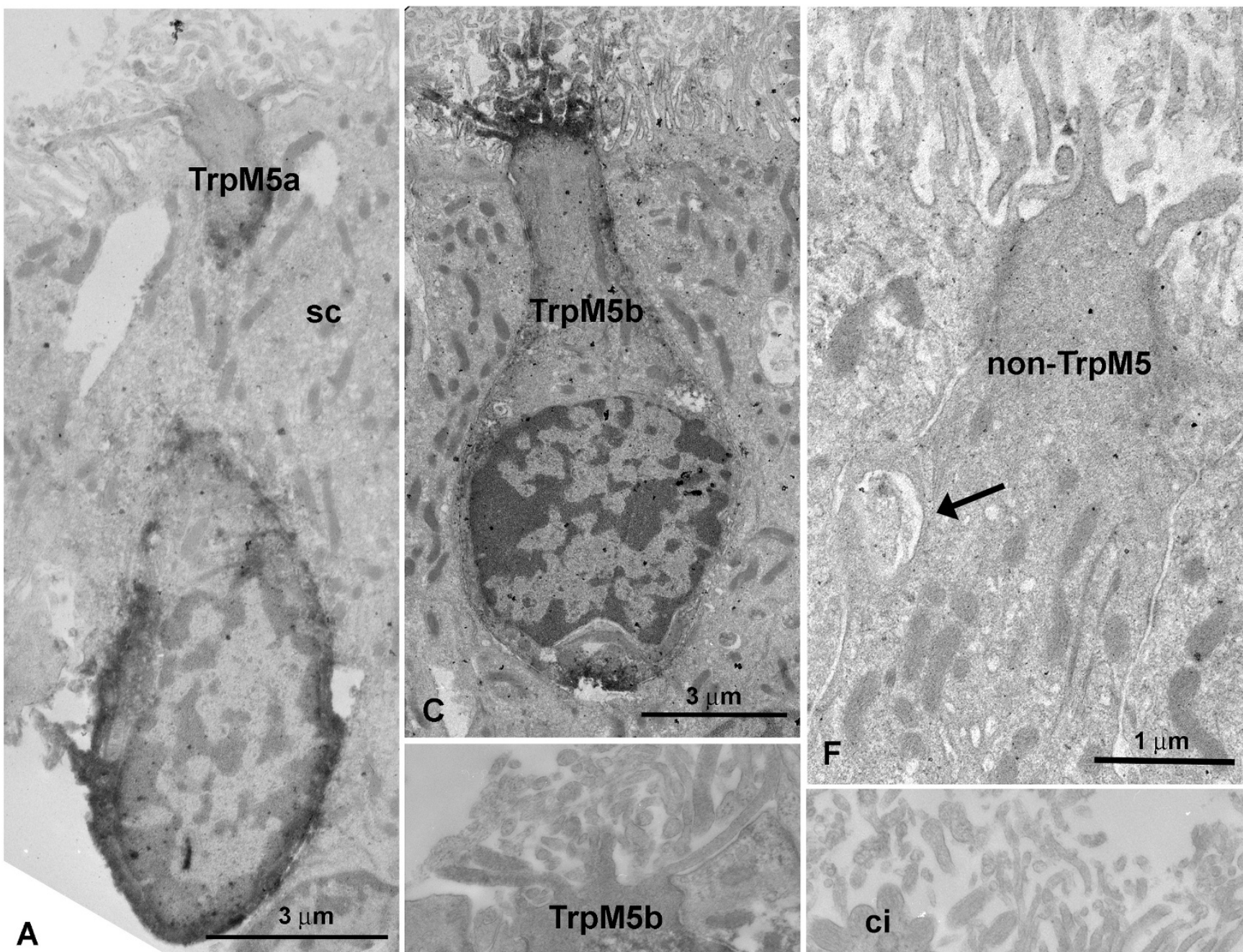

A
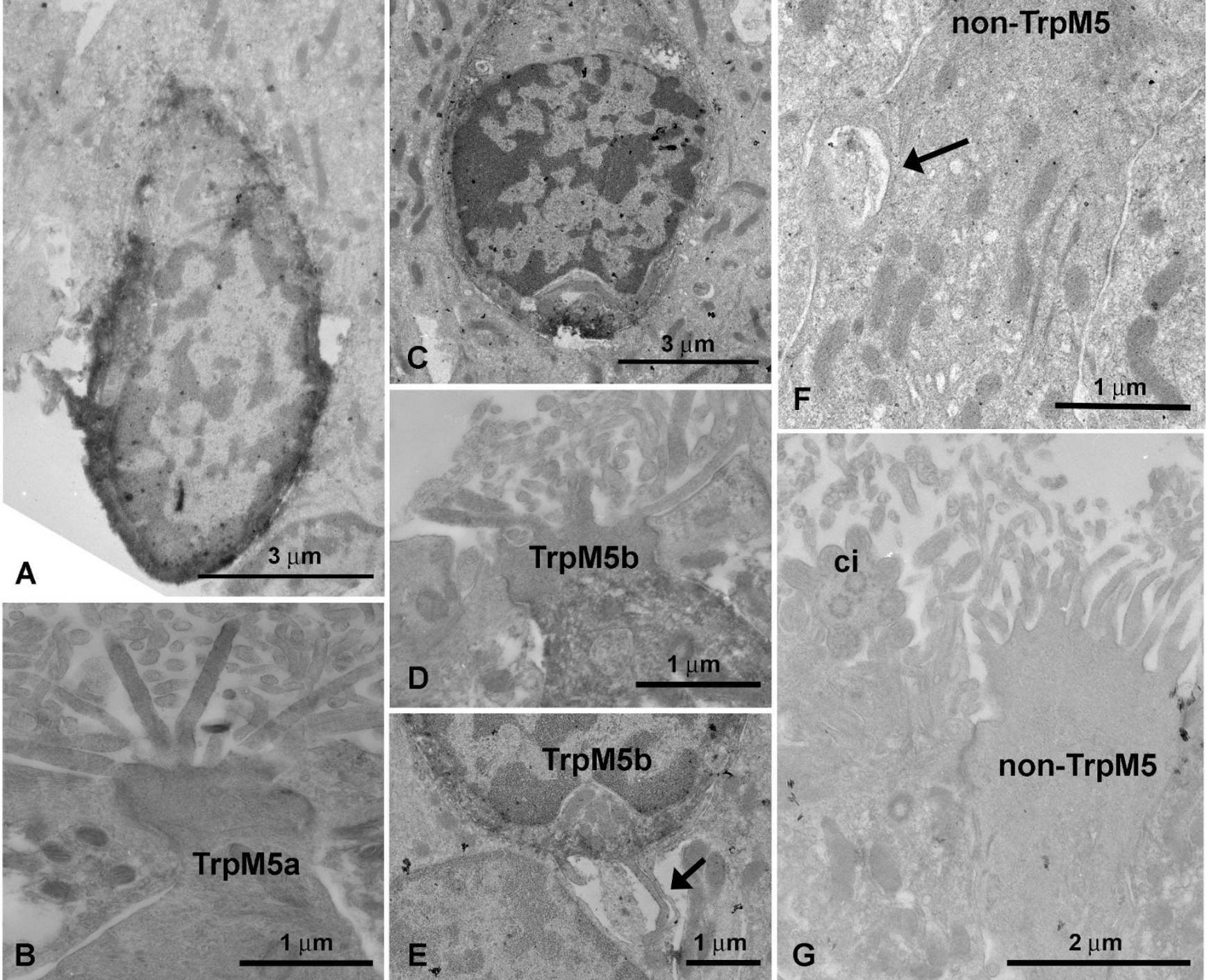

\section{Figure 3}

Electron micrographs of different MV cells in the MOE of transgenic mice. A TrpM5a MV cell labeled with the GFP antibody. Note how the neighboring SC "wraps" around the GFP-+ cell. B Higher magnification of a GFP-+ TrpM5a MV cell. The microvilli radiate from the apex giving the impression of being "stiff". C GFP-+ TrpM5b MV cell. Note the difference in cell size compared to the TrpM5a cell in A. D Higher magnification of the apex of a TrpM5b MV cell. E Basal portion of a TrpM5b MV cell. Small protrusions extend into the interstitium (arrow). F Non-TrpM5 MV cell in a TrpM5-GFP mouse. Arrow: nerve fiber profile adjacent to MV cell. G A non-TrpM5 MV cell in a TrpM5-GFP mouse with different morphology than that in F suggesting that non-TrpM5 MV cells comprise several subpopulations. ci - ciliated ORN. 
of several subsets with different molecular features, and it is possible that one or more of these subpopulations might have an axon that escaped our detection.

\section{TrpM5a type microvillous cell}

The TrpM5a type microvillous cell is a medium-sized microvillous cell spanning half of the height of the olfactory epithelium (ca. 20 micrometer) (Fig. 2B). The main difference compared to the other types of microvillous cells as seen in the electron microscope are the microvilli. TrpM5a type cell microvilli radiate straight from the cell apex giving the impression of being stiff (Fig. 2A, C). The apex of the cell is slightly elevated but does not form a knob as in microvillous olfactory receptor cells of fish. The microvilli are $150-180 \mathrm{~nm}$ wide, $2.0-2.5$ micrometer long (Table 2), i.e. thicker than those of supporting cells but almost as long (Fig. 2C). The cell body contains abundant free ribosomes, some coated vesicles and some filaments, especially in the upper portion of the cell. Mitochondria are longitudinally arranged and more electron-lucent than those of non-TrpM5 type microvillous cells and supporting cells. The filaments of the terminal web of the supporting cells contact TrpM5a type microvillous cells but do not continue within the cell (Fig. 2C). Beneath the junctional complex spines reach out and often "dig" into adjoining supporting cells (Fig. 2C). Centrioles - typical for microvillous olfactory receptor cells are rare. The base of the TrpM5a type microvillous cell tapers out as seen in many non-TrpM5 type microvillous cells. In the TrpM5-GFP-transgenic mouse immunolabeling for GFP confirms expression in TrpM5a type microvillous cells implying that they normally express the TrpM5 channel (Fig. 3A, B).

\section{TrpM5b type microvillous cells}

TrpM5b type microvillous cells only span the upper third of the olfactory epithelium and the length of their cell bodies ranges from 10 to 15 micrometer (Fig. 2D). Their cell bodies are pear-shaped and the lower half of the cell is filled with the nucleus. With $110-130 \mathrm{~nm}$, the width of the microvilli of this cell type lies between those of TrpM5a type and non-TrpM5 type cells. Their length (1.3 -1.5 micrometer, Table 2 ) is similar to the length of nonTrpM5 type microvillous cells and the shape of the microvilli is also similar to that of non-TrpM5 type cells, i.e. they do not give the impression of being stiff as seen in

Table 2: Characteristics of microvilli

\begin{tabular}{lll}
\hline & Length & Width \\
\hline Microvilli of TrpM5a cell & $2.0-2.5 \mu \mathrm{m}$ & $150-180 \mathrm{~nm}$ \\
Microvilli of TrpM5b cell & $1.3-1.5 \mu \mathrm{m}$ & $110-130 \mathrm{~nm}$ \\
Microvilli of non-TrpM5 cell & $1.2-1.8 \mu \mathrm{m}$ & $80-130 \mathrm{~nm}$ \\
Microvilli of supporting cells & $2.0-2.6 \mu \mathrm{m}$ & $65-90 \mathrm{~nm}$
\end{tabular}

TrpM5a type microvillous cells. The apex is flat and not elevated as in TrpM5a type microvillous cells (Fig. 2E). Occasionally, the upper cell body contains multivesicular bodies and/or centrioles(s) (not shown). These centrioles are not connected to rootlets as seen in some non-TrpM5 type microvillous cells. Mitochondria are more electronlucent and shorter than in TrpM5a type microvillous cells. Free ribosomes are less abundant. The basal part of TrpM5b type cells reveals several small filopodia-like appendages that often interdigitate with protrusions of neighboring cells (Fig. 3E). In transgenic TrpM5-GFP mice, TrpM5b type microvillous cells are GFP-positive indicating that they express the TrpM5 channel as do TrpM5a type microvillous cells (Fig. 3D, E).

\section{Non-TrpM5 type microvillous cells}

The cell bodies of non-TrpM5 type microvillous cells have about the same length as those of TrpM5a type cells (ca. 20 micron) (Fig. 2G). The small microvilli occasionally branch (not shown). The width of these microvilli ranges from 80 to $130 \mathrm{~nm}$, their length from 1.2 to 1.8 micrometer. Thus, they are thicker but shorter than the microvilli of supporting cells ( $65-90 \mathrm{~nm}$ width, 2.0 to 2.6 micrometer length, Table 2, Fig. 2G, H). The microvilli sprout from a small knob that is more pronounced than in TrpM5a type microvillous cells. Occasionally one or more centrioles are present in the upper part of the cell beneath the zonula occludens. Small rootlets may or may not be attached to these centrioles (Fig. 2H). Centrioles and rootlets are not present in all microvillous cells and the range of width and length of the microvilli is larger than in TrpM5a type and TrpM5b microvillous cells. Therefore it is possible that the cells described here as non-TrpM5 type microvillous cells represent more than one cell population (see below). The neighboring supporting cells contain a dense terminal web which contacts the microvillous cells. Contrary to the situation in TrpM5a type and TrpM5b microvillous cells (Fig. 2C, E), some filaments of the terminal web are also present in some non-TrpM5 type microvillous cell (Fig. 2H). The apical knob and the cell body contain few light vesicles and coated vesicles. The cell body contains several Golgi apparati, free ribosomes, and bundles of electron-dense filaments. The mitochondria are electron-dense (Fig. 2G, H) whereas the mitochondria in TrpM5a type and TrpM5b cells are electron-lucent (Fig. 2B, D). The nuclei are located at the level of the nuclei of supporting cells, sometimes even higher. The height of the cell from apex to the base where it tapers out is about 20 micrometer. Occasionally, non-TrpM5 type cells are in close contact with nerve fibers. Sometimes the cell "wraps" around these fibers (Fig. 3F). However, we did not detect obvious synapses. This microvillous cell type does not express GFP in the transgenic TrpM5-GFP mouse (Fig. 3F, G). 
To directly test the possibility that these 3 cell types might have an axon, the fluorescent tracer DiI was placed into the olfactory bulb close to the cribriform plate. In TrpM5GFP mice the green fluorescence was lost due to the long incubation in the fixative so that clear double-labeling with DiI was not possible. DiI traveled well into the OE, labeling the typical long slender ORNs. Only rarely was a medium-sized cell spanning the upper half of the epithelium labeled with DiI (Fig. 1C, D). Cells that span only the upper third of the epithelium, i.e. where the TrpM5a and TrpM5b microvillous cells are, were not labeled with DiI.

Given the fact that we could not detect an axon penetrating the basal lamina in either electron microscopic or DiI preparations, we conducted numerous immunohistochemical experiments to substantiate the notion that at least some of these microvillous cells are non-olfactory if not non-sensory cells. We utilized a panel of markers for various cell features (Table 1). Our experiments show that multiple subsets of TrpM5-GFP-negative microvillous cells exist. For the time being we classify these as nonTrpM5 type microvillous cells. Experiments to further distinguish the cell types classified here as non-TrpM5 type cells are underway.

In order to test whether the microvillous cells are innervated by trigeminal nerve fibers [15], we used antisera against CGRP and Substance $P$, markers for trigeminal innervation. Nerve fibers expressing CGRP or Substance $P$ were labeled within and below the olfactory epithelium (Fig. 4A) but we did not see any contact with the TrpM5GFP-positive microvillous cells. However, it is possible that non-TrpM5 type cells are in contact with nerve fibers
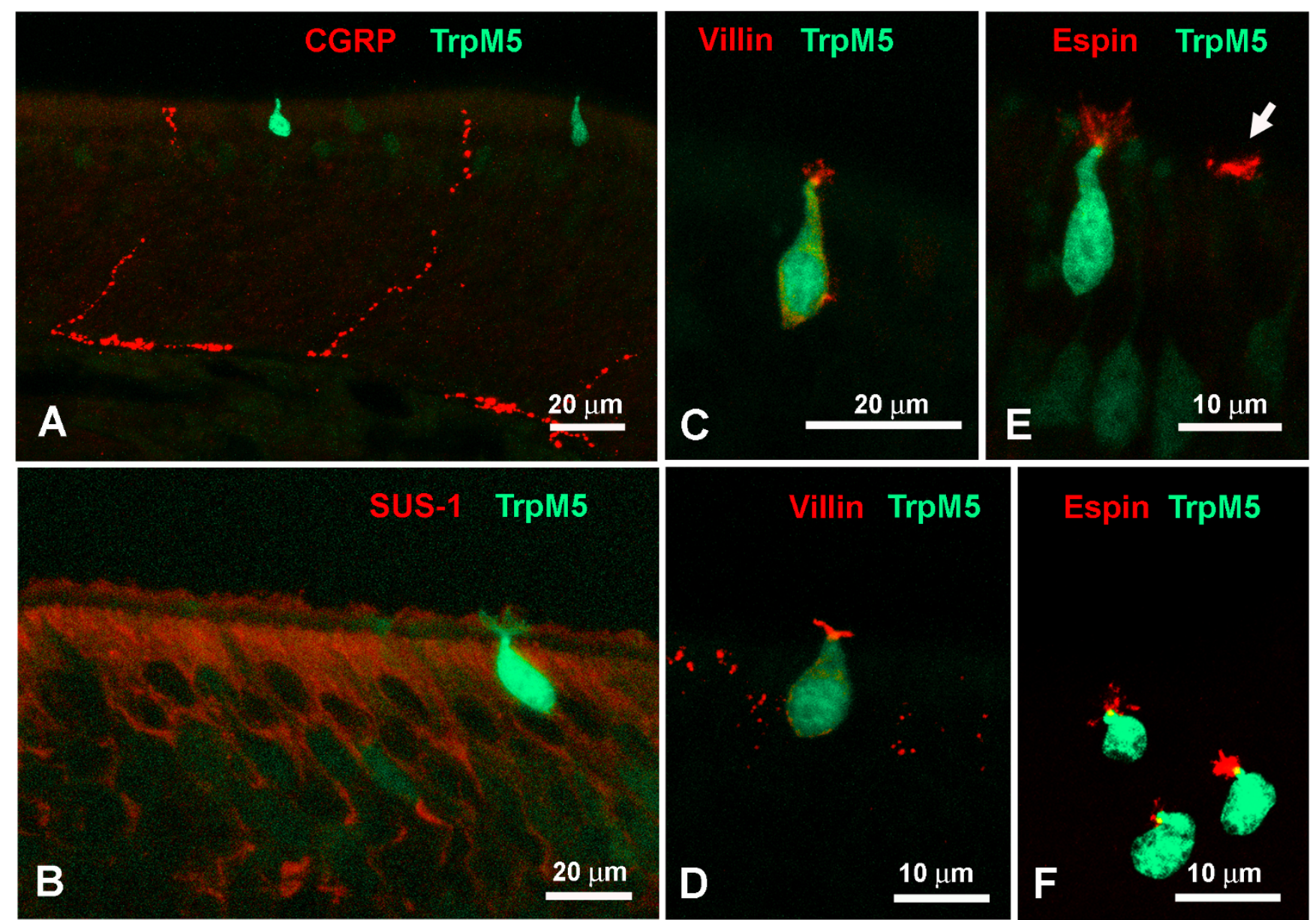

Figure 4

A CGRP-positive nerve fibers are present but do not contact TrpM5-+ cells. B SUS-I labels SCs in the MOE but not TrpM5-+ cells. C GFP-+ TrpM5a cells show villin immunoreactivity in their microvilli and in their cell membranes. D Microvilli and the cell membrane of a GFP-+ TrpM5b cell labeled with villin antisera. E GFP-+ TrpM5a type cells show espin immunoreactivity in their microvilli. In addition to TrpM5-GFP-+ cells some non-TrpM5 cells show espin label (arrow). Some ORNs are slightly GFP-+ but are espin-negative. F Microvilli of GFP-+ TrpM5b cells labeled with espin antisera. 
since we found microvillous cells at the electron microscopic level that are adjacent to nerve fibers (see Fig. 3F). Since the TrpM5-GFP cell bodies lie in the layer of the nuclei of the supporting cells, we tested the SUS-1 antibodies known to label supporting cells in the main olfactory epithelium [16]. TrpM5-GFP cells did not express SUS-1 (Fig. 4B) although surrounding supporting cells do.

Despite the fact that TrpM5a type and TrpM5b type microvillous cells clearly differ in morphology, their expression pattern of cell markers was identical (Table 3). Both types were labeled with espin and villin, markers for microvilli (Fig. 4C-F). In addition to the TrpM5-GFP-positive microvillous cells, some TrpM5-GFP-negative cells of microvillous morphology also were labeled with espin suggesting that these cells belong to the non-TrpM5 type microvillous cell group (Fig. 4E).

To test whether the microvillous cells in question are olfactory neurons we applied OMP, PGP 9.5 and Hu-D, antisera that label ciliated ORNs. Neither TrpM5a type nor TrpM5b microvillous cells expressed OMP or PGP 9.5 (see
Lin, companion paper, this issue), or Hu-D (data not shown) underlining their non-olfactory/non-neuronal character. In order to uncover possible features of these microvillous cells, we tested various antibodies against members of transduction pathways (e.g. P2X3 (Fig. 5A), TrpC6 (Fig. 5B), Gaolf, Gaq/11 (Fig. 5C), PDE2A (Fig. 5D)), synaptic components (e.g. SV2, synaptophysin) and other common cell markers (e.g. CK18, Na+, K+-ATPase, data not shown). Other than espin and villin none of the cell markers used in this study labeled the TrpM5-GFP cells categorized as TrpM5a type and TrpM5b microvillous cells. However, several of these markers were expressed in cells with microvillous morphology (Fig. 5AD) that were TrpM5-GFP-negative. These cells probably belong to the non-TrpM5 type group of microvillous cells and are presently investigated in a separate study.

\section{Discussion}

Our study revealed at least 3 types of microvillous cells in the main olfactory epithelium of mice. Villin and espin, actin-binding proteins typically expressed in microvilli of chemosensory and mechanosensory systems [17] were

Table 3: Antibody pattern in microvillous cells

\begin{tabular}{|c|c|c|c|c|c|}
\hline & $\begin{array}{l}\text { TrpM5a Type MV } \\
\text { cells }\end{array}$ & $\begin{array}{l}\text { TrpM5b Type MV } \\
\text { cells }\end{array}$ & $\begin{array}{l}\text { Non-TrpM5 Type MV } \\
\text { cells }\end{array}$ & Ciliated ORNs & Other tissue controls \\
\hline TrpM5 & +++ & +++ & - & $+*$ & - \\
\hline Calbindin & - & - & ? & ++ & \\
\hline Calretinin & - & - & ? & ++ & \\
\hline Chromogranin A & - & - & - & - & some cells in VNO \\
\hline CKI8 & - & - & ++ & - & \\
\hline Espin & +++ & +++ & +++ & - & \\
\hline CGRP & no contact & no contact & $?$ & no contact & contact to SCCs \\
\hline $\mathrm{Gq} / \mathrm{I}$ & - & - & ++ & - & \\
\hline IP3R3 & - & - & +++ & - & \\
\hline $\mathrm{Na}^{+}, \mathrm{K}^{+}-\mathrm{ATPase}$ & - & - & - & - & nerve fibers, olfactory bulb \\
\hline NSE & - & - & $?$ & ++ & \\
\hline OMP & - & - & $?$ & +++ & \\
\hline $\mathrm{P} 2 \mathrm{X} 2$ & - & - & - & - & $+* *$ \\
\hline $\mathrm{P} 2 \times 3$ & - & - & + & + & \\
\hline PDE2A & - & - & + & $++* * *$ & \\
\hline PGP9.5 & - & - & $?$ & +++ & \\
\hline PLC beta2 & - & - & + & + & \\
\hline Substance $P$ & no contact & no contact & $?$ & no contact & contact to SCCs \\
\hline SNAP 23 & - & - & $?$ & - & synapses in muscle tissue \\
\hline SNAP 25 & - & - & $?$ & - & synapses in muscle tissue \\
\hline SUS-I & - & - & - & - & supporting cells \\
\hline SV2 & - & - & ++ & - & $\begin{array}{l}\text { nerve fibers, synapses in } \\
\text { various tissues }\end{array}$ \\
\hline Synaptophysin & - & - & ++ & ++ & \\
\hline TrpC6 & - & - & $++* * *$ & - & \\
\hline VAChT & - & - & - & - & + in SCCs \\
\hline Villin & +++ & +++ & +++ & - & \\
\hline
\end{tabular}

+++ = abundant; ++ = some; + = few; - = absent; ? = possible but not confirmed by electron microscopy

$\mathrm{MV}=$ microvillous cells

* weakly expressed in some ORNs in limited areas

** P2X2 positive cells are present in the thin epithelium of the turbinates which resemble solitary chemosensory cells (SCCs)

$* * *$ in limited areas 

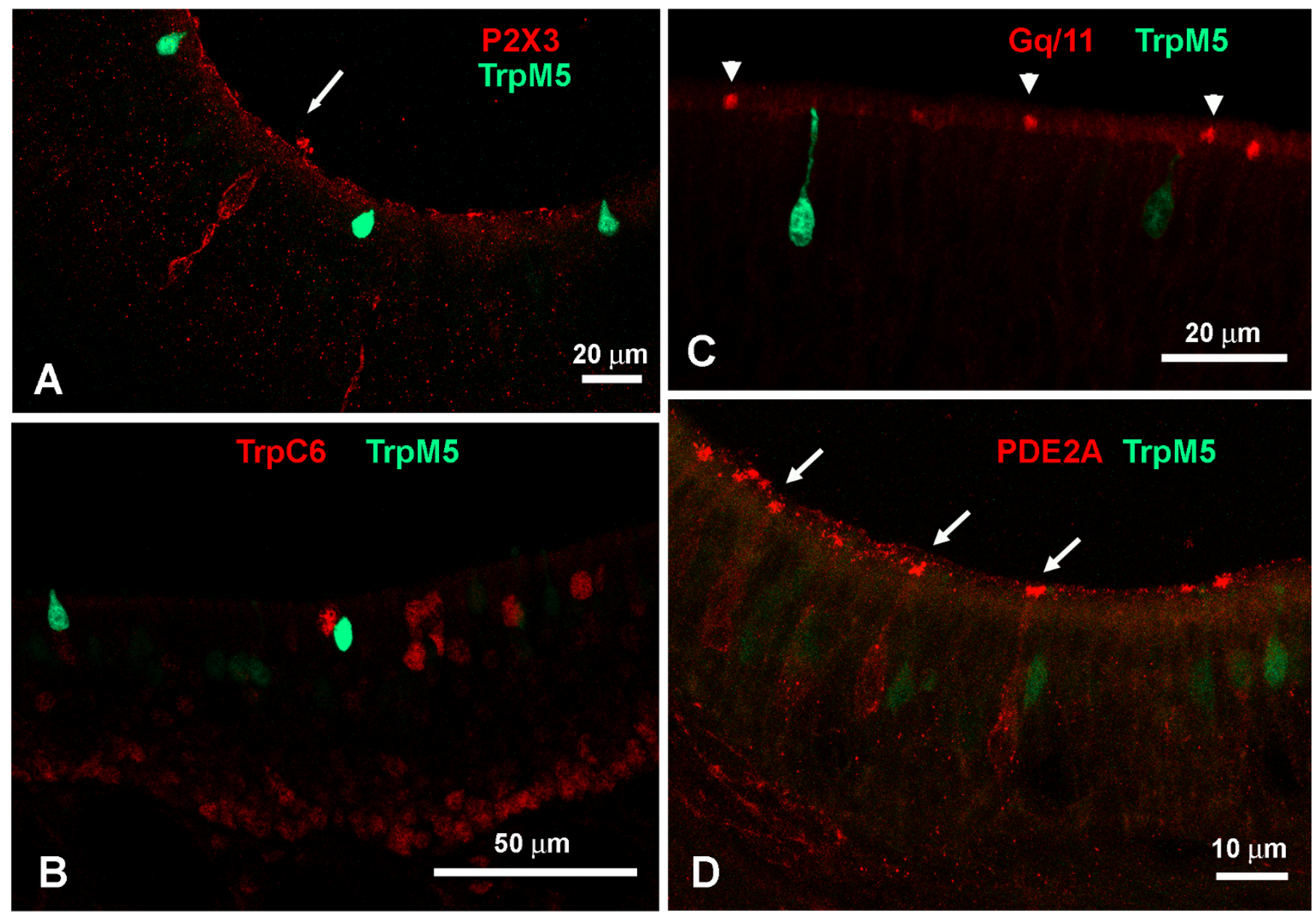

Figure 5

A P2X3 receptor antiserum labels cells with nuclei high in the epithelium but does not label TrpM5-GFP-+ cells (arrow). B Cells located high in the epithelium labeled for TrpC6 show no TrpM5-GFP label. C GFP-+ TrpM5a cells do not double-label with antisera against Gaq/I I. Other presumably MV cells (non-TrpM5) are Gaq/I I-+ (arrowheads). D GFP-+ TrpM5a cells do not express PDE2A. Other cells in the vicinity are PDE2A-+ (arrows).

the only cell markers that labeled all microvillous cell types, confirming that they all bear microvilli. Two of the microvillous cell types show the transient receptor channel TrpM5-GFP label (TrpM5a type and TrpM5b microvillous cells). In addition, electron microscopic as well as immunohistochemical experiments revealed microvillous cells that were TrpM5-GFP-negative and expressed other cell markers not seen in the TrpM5-GFP cells. We group these cells as non-TrpM5 type microvillous cells. None of the types of microvillous cells described in this study have an axon that penetrates the basal lamina nor did we detect synapses consistent with findings from other studies.

Kaske et al. studied cells in various tissues that expressed TrpM5 and postulated that TrpM5 is an intrinsic signaling component that plays a physiological role in olfaction of odorants and pheromones [12]. As TrpM5 is also present in cells of the taste and gastrointestinal system the authors claim that TrpM5 is a marker for chemosensory cells. Lin et al. also found solitary chemosensory cells in the respiratory epithelium that are TrpM5-positive [18]. If TrpM5 is a marker for chemosensory cells, the TrpM5-positive cells should express other characteristics of chemosensory cells including contact with the nervous system as well as members of the chemosensory transduction pathway, and/or other markers of ORNs like OMP, PGP 9.5 etc. In the case of the solitary chemosensory cells, Lin et al. showed that TrpM5-positive cells are also labeled by antisera against PLC $\beta 2$ and PGP 9.5, known markers for chemosensory cells [18]. Yet, none of these components double-labeled the microvillous TrpM5-GFP-positive cells in our study. Also, the antibody SUS- 1 which is specific for olfactory supporting cells did not label the TrpM5-positive cells. Thus, based on the present study, we conclude that the TrpM5-GFP-positive cells - termed here TrpM5a type and TrpM5b type microvillous cells - are not among 
the cells traditionally described as comprising the olfactory epithelium, i.e. olfactory receptor cells, supporting cells, and basal cells. Since none of the neuronal cell markers tested showed a positive result, and the cells have neither an axon projecting to the olfactory bulb nor contact to nerve fibers of trigeminal origin, it is not even clear whether these cells are sensory cells at all. At least for chemosensory cells we question the reliability of TrpM5 as a marker. However, we do not rule out that the TrpM5GFP-positive microvillous cells may be chemoresponsive and influence local mucosal elements through the release of diffusible mediators.

A recent study on mouse and rat olfactory epithelium described microvillous cells labeled with antibodies against IP3R3 and PLC 32 [10]. These microvillous cells did not degenerate after bulbectomy suggesting that they are not ORNs. The authors claimed that these cells express the transient receptor channel TrpC6 although they did not show double-label experiments for TrpC6 and either IP3R3 or PLC $\beta 2$. In the present study we did not see any cells double-labeled for TrpM5 and TrpC6. Neither did the TrpM5-GFP-positive cells double-label for IP3R3 or PLC 32 (see also Lin et al., companion paper, this issue). Consequently, we postulate that the TrpM5-GFP-positive microvillous cells are not the ones shown in the study by Elsaesser [10]. It is likely that the TrpC6 cells belong to the group of non-TrpM5 type microvillous cells.

In the past, several studies mentioned microvillous cells in the main olfactory epithelium of rodents, e.g. $[19,20]$. Since the morphological descriptions varied and the proposed functions were often controversial, these studies received little attention. Okano et al. [21] postulated that microvillous cells in the olfactory epithelium of dogs were precursors of supporting cells. Bannister [22], based on the electron microscopic descriptions of the chicken olfactory epithelium [23], suggested that microvillous cells may be precursors for ciliated olfactory neurons. This hypothesis was rejected by Jourdan [20] since both cell types have very distinct features and no "intermediate" stages between microvillous and ciliated olfactory neurons have ever been detected.

Others have attributed various functions to these microvillous cells in addition to the notion of being precursor cells. One central question was: Are the microvillous cells true ORNs? Rowley and coworkers conducted experiments with HRP as a neural tracer and showed that microvillous cells could be retrogradely labeled from the rat olfactory bulb [24]. The authors mentioned, however, that a small percentage of microvillous cells "did not effectively transport HRP" from the olfactory bulb to their somata. There is also the possibility of nonspecific labeling. A study on the OE of fish reported a third type of
ORN labeled by fluorogold [25]. Later it was shown that the fluorogold labeled cells in the OE nonspecifically [26]. In the present study we did not find any evidence of an axon projecting towards the olfactory bulb which would have been proof that these microvillous cells are, indeed, ORNs. Although we cannot rule out completely that we may have missed cells with an axon in our ultrathin $(70 \mathrm{~nm})$ serial sections, we conclude that the microvillous cells described in this study are not ORNs.

Several authors reported microvillous cells without an axon, i.e. cells that were not ORNs. For instance, Carr et al. [7] described a microvillous cell in the rat olfactory epithelium. These cells had no axon and survived ablation of the olfactory bulb but did not react with the marker for supporting cells SUS-1. Thus these cells do not belong to the olfactory system in the strict sense of basal, supporting, and olfactory receptor cells.

Occasionally the morphological features of microvillous cells reported in the past are similar to the features seen in microvillous cells of this study. Miller and coworkers described microvillous cells in the rat olfactory epithelium in a study of regeneration following exposure to toxic compounds [27]. These cells had no synapses but finger-like processes extending between the supporting cells. Also, histochemical staining with ecto-5'-nucleotidase revealed microvillous cells in the rat olfactory epithelium that had numerous invaginations interdigitating with the cell membranes of neighboring supporting cells [28]. We noted numerous processes of TrpM5b and nonTrpM5 type microvillous cells interdigitating with other cells, and also invaginations in non-TrpM5 microvillous cells. Asan and Drenckhahn [5] described two types of microvillous cells in rat and mouse. Among others, the authors showed microvillous cells labeled with antibodies against villin and CK 18 . In the present study we detected villin in TrpM5a, TrpM5b and non-TrpM5 microvillous cells whereas CK 18 labeled only non-TrpM5 microvillous cells. It is probable that some of the microvillous cells seen in this study may be the microvillous cells described by $[7,27,4]$, or $[5]$.

\section{Conclusion}

Our study shows that the mouse olfactory epithelium contains different types of microvillous cells. The cell types described in this study do not have an axon, i.e. are not ORNs. The broad reaction spectrum to various cell markers seen in this study and in the literature implies the existence of several subpopulations of microvillous cells. Their function is enigmatic. Further experiments are needed to elucidate the role of these cell populations and their possible connection to the olfactory and/or other sensory systems. 


\section{Authors' contributions}

$\mathrm{AH}$ participated in the design of this study, carried out the experiments at the light and electron microscopic level, and drafted the manuscript. TEF participated in the design and coordination and helped with the manuscript. Both authors read and approved the final manuscript.

\section{Acknowledgements}

The authors thank Dr. Robert Margolskee (Mount Sinai School of Medicine, New York) for providing the TrpM5-GFP mice and Drs. Weihong Lin (University of Baltimore) and Diego Restrepo (University of Colorado) for valuable comments on this manuscript. We thank Dr. Frank Margolis for the antibodies against OMP and SUS-I. This study was supported by NIDCD grants DC 007732 (AH), DC 06070 (Diego Restrepo and TEF), and P30 DC 04657 (Diego Restrepo and TEF).

\section{References}

I. Ache BW, Restrepo D: Olfactory transduction. In The Neurobiology of Taste and Smell Edited by: Finger TE, Silver WL, Restrepo D. New York: John Wiley-Liss and Sons, Inc; 2000:159-177.

2. Moran DT, Rowley C III, Jafek BW: Electron microscopy of human olfactory epithelium reveals a new cell type: The microvillar cell. Brain Res 1982, 253:39-46.

3. Yamagishi M, Nakamura H, Nakano Y, Kuwano R: Immunohistochemical study of the fourth cell type in the olfactory epithelium in guinea pigs and in a patient. ORL 1992, 54:85-90.

4. Braun N, Zimmermann H: Association of ecto-5'-nucleotidase with specific cell types in the adult and developing rat olfactory organ. J Comp Neurol 1998, 393:528-537.

5. Asan E, Drenckhahn D: Immunocytochemical characterization of two types of microvillar cells in rodent olfactory epithelium. Histochem Cell Biol 2005, I 23:157-168.

6. Rowley JC III, Moran DT: HRP applied to transected trout olfactory nerves fills ciliated receptors, microvillar receptors, and some basal cells. Chem Senses 1985, 10:392-393.

7. Carr VM, Farbman Al, Colletti LM, Morgan Jl: Identification of a new non-neuronal cell type in rat olfactory epithelium. Neuroscience 1991, 45:433-449.

8. Juilfs DM, Fülle HJ, Zhao AZ, Houslay MD, Garbers DL: A subset of olfactory neurons that selectively express CGMP-stimulated phosphodiesterase (PDE2) and guanylyl cyclase-D define a unique olfactory signal transduction pathway. Proc Natl Acad Sci USA 1997, 94:3388-3395.

9. Lin W, Arellano J, Slotnick B, Restrepo D: Odors detected by mice deficient in cyclic nucleotide-gated channel subunit A2 stimulate the main olfactory system. J Neurosci 2004, 24:3703-37I0.

10. Elsaesser R, Montani G, Tirindelli R, Paysan J: Phosphatidylinositide signaling proteins in a novel class of sensory cells in the mammalian olfactory epithelium. Eur J Neurosci 2005, 21:2692-2700.

II. Lin W, Margolskee RF, Hansen A, Restrepo D: Microvillar nonolfactory cells in the main olfactory epithelium. Chem Senses 2007, 32:231.

12. Kaske S, Krasteva G, König P, Kummer W, Hofmann T, Gudermann T, et al.: TRPM5, a taste-signaling transient receptor potential ion-channel, is a ubiquitous signaling component in chemosensory cells. BMC Neuroscience 2007, 8:

13. Clapp TR, Medler KF, Damak S, Margolskee RF, Kinnamon SC: Mouse taste cells with $G$ protein-coupled taste receptors lack voltage-gated calcium channels and SNAP-25. BMC Biology 2006, 4:

14. Lin W, Margolskee RF, Donnert G, Hell SW, Restrepo D: Olfactory neurons expressing transient receptor potential channel M5 (TRPM5) are involved in sensing semiochemicals. Proc Natl Acad Sci USA 2007, 104:247|-2476.

15. Finger TE, St Jeor VL, Kinnamon JC, Silver WL: Ultrastructure of substance $P$ - and CGRP-immunoreactive nerve fibers in the nasal epithelium of rodents. J Comp Neurol 1990, 294:293-305.

16. Hempstead JL, Morgan Jl: A panel of monoclonal antibodies to the rat olfactory epithelium. J Neurosci 1985, 5:438-449.
17. Sekerkova G, Zheng L, Loomis PA, Changyaleket B, Whitlon DS, Mugnaini $E$, et al.: Espins are multifunctional actin cytoskeletal regulatory proteins in the microvilli of chemosensory and mechanosensory cells. J Neurosci 2004, 24:5445-5456.

18. Lin W, Ogura T, Margolskee RF, Finger TE, Restrepo D: TRPM5expressing solitary chemosensory cells respond to odorous irritants. J Neurophysiol 2008, 99: |45|-|460.

19. Andres KH: Der olfaktorische Saum der Katze. Z Zellforsch 1969, 96:250-274.

20. Jourdan F: Ultrastructure de l'épithélium olfactif du rat: polymorphisme des récepteurs. CR Acad Sci 1975, 280:443-446.

21. Okano M, Weber AF, Frommes SP: Electron microscopic studies of the distal border of the canine olfactory epithelium. J Ultrastruct Res 1967, 17:487-502.

22. Bannister $\mathrm{LH}$ : The fine structure of the olfactory surface of teleostean fishes. Quart J Microsc Sci 1965, 106:333-342.

23. Sotelo JR, Trujillo-Cenóz O: Electron microscope study on the development of ciliary componenets of the neural epithelium of the chick embryo. Z Zellforsch 1958, 49: I-12.

24. Rowley JC III, Moran DT, Jafek BW: Peroxidase backfills suggest the mammalian olfactory epithelium contains a second morphologically distinct class of bipolar sensory neuron: the microvillar cell. Brain Res 1989, 502:387-400.

25. Muller JF, Marc RE: Three distinct morphological classes of receptors in fish olfactory organs. J Comp Neurol 1984 , 222:482-495

26. Morita $Y$, Finger TE: Differential projections of ciliated and microvillous olfactory receptor cells in the catfish, Ictalurus punctatus. J Comp Neurol 1998, 398:539-550.

27. Miller ML, Andringa A, Evans JE, Hastings L: Microvillar cells of the olfactory epithelium: morphology and regeneration following exposure to toxic compounds. Brain Res 1995, 669:I-9.

28. Braun N, Zimmermann H: Association of ecto-5'-nucleotidase with specific cell types in the adult and developing rat olfactory organ. J Comp Neurol 1998, 393:528-537.
Publish with BioMed Central and every scientist can read your work free of charge

"BioMed Central will be the most significant development for disseminating the results of biomedical research in our lifetime. "

Sir Paul Nurse, Cancer Research UK

Your research papers will be:

- available free of charge to the entire biomedical community

- peer reviewed and published immediately upon acceptance

- cited in PubMed and archived on PubMed Central

-yours - you keep the copyright 